\title{
Stimulating collective action to preserve High Nature Value farming in post-transitional settings. A comparative analysis of three Slovenian social- ecological systems
}

\author{
Ilona Rac', Luka Juvančič́', Emil Erjavec \\ I University of Ljubljana Biotechnical Faculty, Jamnikarjeva 101, SI-1000 Ljubljana, Slovenia \\ Corresponding author: Ilona Rac (ilona.rac@bf.uni-lj.si)
}

Academic editor: M. Blicharska | Received 17 February 2020 | Accepted 31 March 2020 | Published 22 May 2020

http://zoobank.org/6967B4EB-3E5B-4BDF-8EEF-EFC05EF9B3C6

Citation: Rac I, Juvančič L, Erjavec E (2020) Stimulating collective action to preserve High Nature Value farming in post-transitional settings. A comparative analysis of three Slovenian social-ecological systems. Nature Conservation 39: 87-111. https://doi.org/10.3897/natureconservation.39.51216

\begin{abstract}
The main research challenge of this paper is to gain a better understanding of collective action to preserve High Nature Value (HNV) farming in the specific setting of post-transitional EU Member States of Central and Eastern Europe, which we explore using Slovenia as a model country. We apply the Socialecological Systems (SES) framework and combine participatory and action research in considering different options for stimulating collective action of local actors in three social-ecological systems in Slovenia. We describe the systems, focussing on first-tier variables, and provide a comparison of their characteristics influencing the readiness to engage in collective action. Characteristics of system actors had the greatest influence on outcomes, followed by the social, economic and political setting (macro issues) and governance arrangements. Strong leaders enjoying the community's trust are needed; rules must be transparent and individuals must have a personal interest to engage in cooperation. In a post-transitional setting, overcoming the issue of lack of trust is a limiting factor when attempting to stimulate collective action.
\end{abstract}

\section{Keywords}

Social-ecological systems, Post-transitional setting, HNV farming, Conservation, Resource management

Copyright llona Rac et. al. This is an open access article distributed under the terms of the Creative Commons Attribution License (CC BY 4.0), which permits unrestricted use, distribution, and reproduction in any medium, provided the original author and source are credited. 


\section{Introduction}

Traditional European extensive agricultural systems are not only a source of food and fibre and farmers' incomes, but also the main reason for the historical development of species-rich semi-natural habitats and cultural landscapes considered to be public goods (Cooper et al. 2009). A substantial proportion of European biodiversity (including domesticated plants and animals) depends on extensive High Nature Value (HNV) farming systems, a concept introduced in the 1990s to describe farming systems associated with high biodiversity and mostly with low chemical inputs and stocking densities (Hoogeveen et al. 2004). These farming systems, which tend to be labour-intensive but create low incomes from the market (O'Rourke and Kramm 2012), are being abandoned across Europe due to either intensification of production or farm abandonment (European Union 2018; Díaz et al. 2016; McGinlay et al. 2017; Sutcliffe et al. 2015; Ustaoglu and Collier 2018). Consequently, there are strong Europe-wide trends of declining farmland biodiversity (European Union 2018; European Commission 2019), farmland abandonment, overgrowth (Perpiña Castillo et al. 2018) resulting in loss of production potential, and depopulation (ESPON 2017). Therefore, the question arises as to how farmers as land managers can be incentivised to continue managing their land in a way that preserves environmental and social benefits, such as farmland biodiversity, cultural landscapes and rural vitality (Dwyer et al. 2018). This paper builds on previous research demonstrating the potential of doing this through improved market valorisation of products stemming from marginal production systems through collective action of smallholders, which helps to reduce transaction costs through resourcepooling (e.g. Kruijssen et al. 2009, Gruère et al. 2009).

Being resource management systems, HNV farming (and agricultural systems in general) can be conceptualised as social-ecological systems (SES) (Ostrom 2007, 2009; McGinnis and Ostrom 2014). This means that we consider them to be an inseparable combination of social and ecological elements. They consist of the human system, i.e. people and their interactions, and the natural system or ecosystem. The main advantage of the SES framework in analysing resource management systems is that it takes into account both of these sub-systems and their interactions. It thus examines systems' building blocks in order to understand how institutions and people co-produce outcomes in terms of appropriation and governance of natural resources (Schoon and Van der Leeuw 2015). It builds on empirical work on managing common pool resources, as well as research on institutions and collective action (Partelow 2018); although today the framework is viewed more as a diagnostic tool for assessing the sustainability of systems (Ostrom 2009), the aspect of collective action for sustainable resource management remains very relevant.

The basic framework organises SESs into four basic interacting entities or subsystems: resource units extracted by resource users from a resource system. Resource users determine the maintenance of the resource system according to a certain governance system (rules and procedures) and in the context of ecological systems and broader socio-political-economic settings. The processes of extraction and maintenance rep- 
resent the most important forms of interactions and outcomes and are located at the centre of the framework (Cumming 2014; McGinnis and Ostrom 2014). One of the framework's advantages is its flexibility; it has been expanded and applied to numerous different situations in assessing the sustainability of SESs (Partelow 2018). One such expansion of the framework is the conceptualisation of agricultural and forestry systems as not only extractors of biomass, but as systems in which human action and natural processes interact to jointly provide environmental and social services (Dwyer et al. 2018); this application draws on the concepts of ecosystem services (Costanza et al. 1997; Daily 1997) and public goods (Samuelson 1954; Musgrave 1959). It is this conceptualisation that is used in the present paper, applied to HNV farming systems, in which farmers are seen not merely as resource users but as actors interacting with the ecological system to provide certain services that would otherwise not exist, i.e. agricultural landscapes, biodiversity specific to these landscapes and rural vitality.

Post-transitional EU member states have retained relatively large species-rich areas (Sutcliffe et al. 2015; ESPON 2017). Although the threats of future abandonment or intensification are highly likely in these countries, literature on managing common resources and on stimulating collective action here is scarce, as opposed to the rich practical and scientific experience in Western Europe (Sandberg et al. 2013; Mike and Megyesi 2018). However, previous research has shown that trust, social capital and readiness to cooperate (preconditions for collective action) are generally low in post-communist countries, regardless of whether they belonged to the Soviet bloc or the 'softer' more market-orientated "socialism" (Estrin 1991; Uvalić 2018) of (ex-)Yugoslavia (e.g. Swain 2000; Murray 2005; Sapsford and Abbott 2006; Lawrence 2008; Scrieciu 2011). In prior research, promoting the sustainable management of biodiversity (specifically in protected areas) in post-communist countries through markets has been explored and shown to be challenging (Otto and Chobotova 2013). However, the potential for stimulating collective action and commercial cooperation is less explored (Scrieciu 2011), although it is particularly pertinent for the same farm structure that is the most relevant for HNV farming (i.e. predominantly low-input, labour-intensive subsistence farming). The main research challenge of this paper is to gain a better understanding of collective action to preserve HNV farming in the specific setting of post-transitional EU Member States of Central and Eastern Europe, taking Slovenia, a former socialist EU Member State with a high proportion of HNV farmland (ARSO 2008), as a model case. Our research question, which asks which are the main factors influencing the willingness and ability of local actors to engage in this kind of collective action, is approached by considering different options for stimulating it in three social-ecological systems in this country.

As many inhabitants of traditional farming landscapes are poor (Fischer et al. 2012) and extensive HNV farming practices are largely being abandoned due to their low profitability (O'Rourke and Kramm 2012), our research explored the possibility of stimulating collective action to engage in a form of improved market valorisation of value-added products from protected areas (in the present case, Landscape parks as defined by the Slovenian Nature Conservation Act, and Natura 2000 areas) and the 
area of the wider communities in which they are embedded, in order to improve local livelihoods and thus hopefully detract from abandonment or intensification. Namely, previous research shows that it is possible to add value to existing products stemming from HNV farming by better communicating to consumers their provenance, which is becoming increasingly relevant in light of changing consumer preferences (e.g. World Bank 2007; Jarvis et al. 2011; Scrieciu 2011). This potential, if appropriately harnessed, could have wide-ranging implications for the numerous small, semi-subsistence farms in the European Union in general and the Central and Eastern European countries (CEEC) in particular - in 2010, farms smaller than 5 ha represented $67 \%$ of all holdings in the EU-27 and this amounted to $78 \%$ of farms in New Member States (Davidova et al. 2013).

The paper is organised as follows. Following a description of the methods of analysis, we provide an analytical description of the main elements of each SES, applying the modified framework developed by Dwyer et al. (2018). This is followed by the results of our attempt at stimulating collective action towards improving the valorisation of the products stemming from these systems and a comparison of findings from all three systems. We then discuss our findings against the backdrop of previous research and finish with some concluding thoughts.

\section{Methods}

The study combined participatory (Cornwall and Jewkes 1995) and action (McIntyre 2007) research, meaning that the research group was actively engaged in attempting to affect the trajectories of the social-ecological systems (Ostrom 2007, 2009; McGinnis and Ostrom 2014). The research mainly took place in the period 9/2015-7/2016, with some information gathered in follow-up interviews in 2018 (for total number and structure of people engaged, see Table 1). Authors conducted coding manually and independently, with regular checking of the coding process to limit potential inconsistencies.

In selecting the cases, we sought areas that are typical cases of HNV farming systems that contain important habitats under the European Union's Natura 2000 (N2K) network and are currently socially (depopulation, low incomes and educational levels) and/or ecologically (habitat degradation, biodiversity loss) threatened. The three cases were selected to be rounded (geographically, administratively or socially) socialecological systems, representative of HNV farming systems in different geographical areas and of different sizes and to represent different levels of agricultural management intensity (CS1 - low intensity; CS2 - medium intensity; CS3 - high intensity) and different levels of familiarity with nature conservation in the form of Landscape parks (CS1 - 28 years; CS2 - 13 years; CS3 - not established). Thus, CS1 (Solčavsko) covered agri-forestry in low-intensity systems in a sub-alpine region; CS2 (Goričko) covered medium-intensity subsistence farming in a hilly region; and CS3 (Središče) covered high-intensity farming in river lowlands, adjacent to a riparian forest. Despite the fact that the concept of High Nature Value farming has been around since the 
Table I. Description of focus groups and interviews and their attendants/interviewees. Source: authors.

\begin{tabular}{lccc}
\hline \multicolumn{1}{c}{ Case study } & Solčavsko (CS1) & Goričko (CS2) & Središče (CS3) \\
\hline $\mathrm{N}^{\circ}$ focus groups & 6 & 2 & 1 \\
$\quad$ Total number of focus group participants & 47 & 26 & 13 \\
Other meetings $^{\mathrm{b}}$ & 8 & 2 & 4 \\
$\mathrm{~N}^{\circ}$ interviews $^{\mathrm{b}}$ & 26 & 14 & 13 \\
$\quad$ Farmers $^{\mathrm{n}}$ & 13 & 14 & 9 \\
Entrepreneurs & 7 & & $2(1)$ \\
Extension officers & 3 & & 1 \\
Municipality officials & 3 & & $1(4)$ \\
NGO representatives & $(2)$ & & \\
Other & $(2)$ & & \\
\hline
\end{tabular}

aattendants of multiple focus groups only listed once

${ }^{b}$ some interviewees belonged to several categories; numbers in parentheses indicate that the interviewee has already been listed in another category

1990s, indicators and monitoring methods are still not fully developed (Lomba et al. 2014, Keenleyside et al. 2014). The only national assessment of HNV farming in Slovenia known to the authors was quite broad-brushed, based on Corine Land Cover and national land use data and estimated $60-80 \%$ of utilised agricultural area (UAA) in Slovenia as HNV farmland (ARSO 2008). Since we could not rely exclusively on this assessment, we used the Natura 2000 classification and association with Landscape Parks (defined by the Nature Conservation Act as "area(s) of high quality and longlasting interconnection of man and nature of great ecological, biological or landscape value") as indirect indicators that they are indeed associated with high biodiversity, as both systems rely on using expert conservation guidelines and indicator species to merit classification as Natura area/Landscape Park.

We deliberately sought out partners seeking help in stimulating collective action for improved market valorisation in concrete cases - regional developers in CS1, a Landscape Park director in CS2 and a national NGO in CS3. We looked for partners whom we knew to have a good knowledge of local dynamics, as well as a stance that sought to reconcile nature-related considerations with social ones.

The research approach consisted of two parts (see Fig. 2). In the first part, we described the social-ecological systems (Fig. 1), focussing on first-tier variables: actors, resource system, resources (environmental and social services), governance (rules and institutions) and broader macro issues - social, economic and political setting (Table 3 ). The action situation in our cases is associated with the attempt to stimulate collective action for improved market valorisation (Table 4) and was the focus of the second, action-based part of our research. In describing the variables, we took a broad-brush approach, as the aim of analysis was not to describe every detail, but to understand the functioning of the systems as a whole. Specifically, the focus in this analysis was more on the human aspects of the system than on the physical quantification of resource extraction and service provision, as our aim was to explore the factors influencing the ability and willingness of the systems' actors (mainly land managers, but depending on 


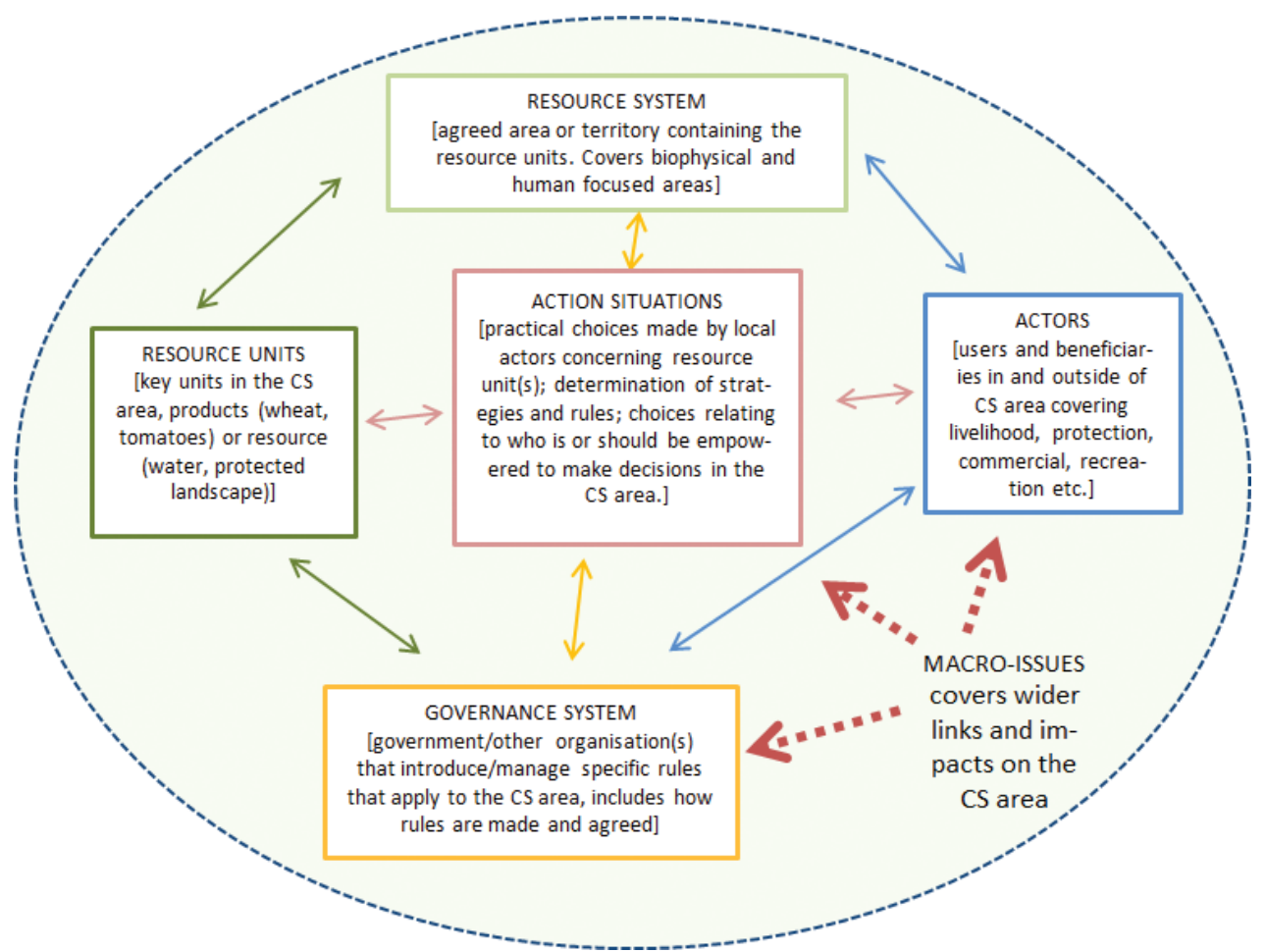

Figure I. The SES diagram. Source: PEGASUS project, based on McGinnis and Ostrom, 2014.

the specific context in each case study area; see next section) to engage in collective action. Qualitative methods of analysis are preferable to quantitative ones in cases when understanding of human behaviour is sought, as it allows for the understanding of context and processes (Maxwell 2012), while the relative level of abstraction of the SES framework, which organises elements of systems into variables, still allows for some level of comparison between systems (Partelow 2018).

The first part of the research was conducted in several steps:

- Initial screening of scientific and grey literature, statistical data and web pages on the case study areas for information on their demographic, economic, geographical, biodiversity-related and agricultural production characteristics, as well as historical development.

- $\quad$ Preparation of preliminary textual descriptions of the basic elements of each SES that were then distilled into tables briefly describing each system's first-tier variables as listed above.

- Verification at meetings with one or several key informants for each case, whom we knew, based on prior experience (e.g. through preceding project collaboration or the persons' prominence in certain fields), to be knowledgeable regarding the respective systems. These gatekeepers helped us to improve the descrip- 


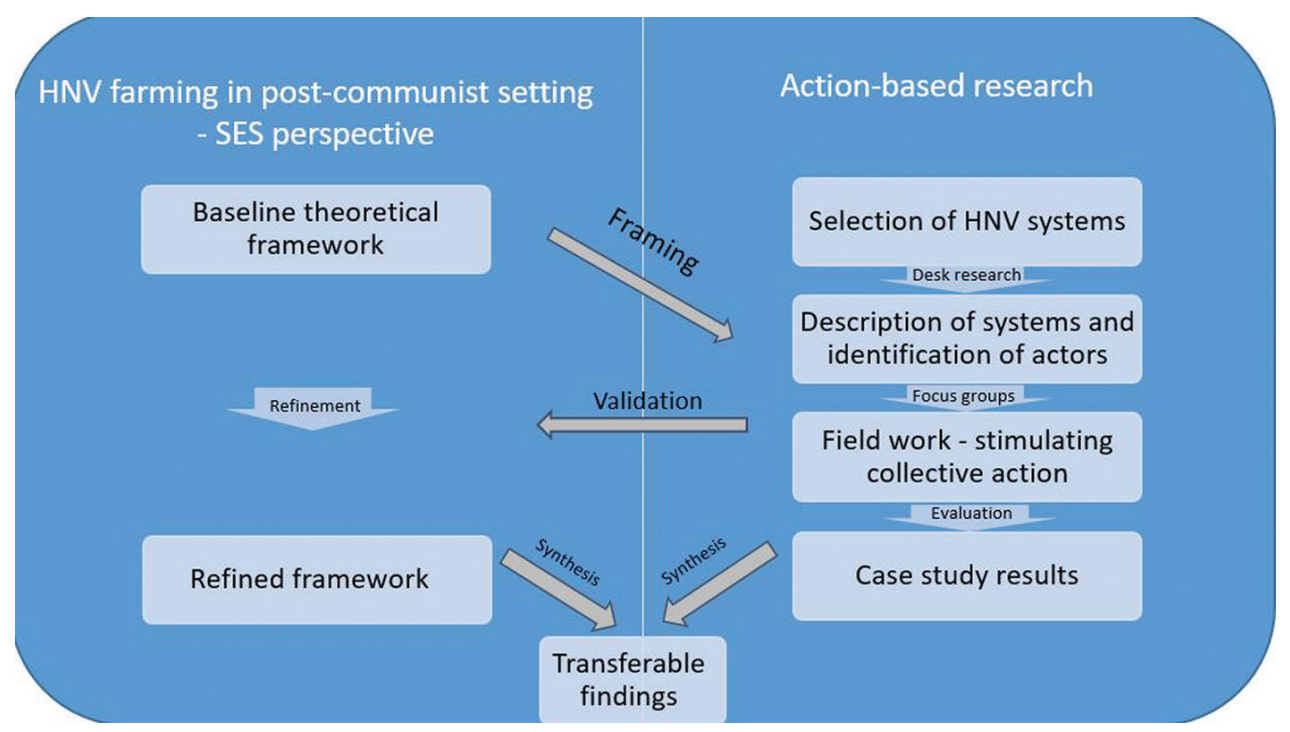

Figure 2. Depiction of the workflow of the research.

tions by providing additional information and to assemble a list of the main actors (land managers who are local opinion leaders, municipality officials, tourist operators, advisory service officials, business owners, NGOs - local associations and other locally prominent persons) in each case study who were then invited to participate in a focus group meeting.

- $\quad$ Presentation of the descriptions of each SES and its main elements to focus group participants and gathering of further feedback at meetings. Subsequently, we discussed with each group the possibility of stimulating local collective action that could, in their view, contribute most to improving the valorisation of their products, while preserving HNV farming.

In the second part of the study, we prepared questionnaires for each case, based on the findings of focus groups, and conducted a total of 53 semi-structured interviews with actors (farmers, entrepreneurs, representatives of local non-governmental organisations and advisory services, municipal officials). In these interviews, we checked the readiness for, attitudes towards and obstacles to collective action, whose specific nature differed in each case. The lists of persons to be interviewed were provided by the local gatekeepers, based on their familiarity with their economic activity and willingness to cooperate. Based on the interviews, our research group prepared a proposal for action, which was presented back and discussed in the broader community at a public final event in each case. Based on any new information provided, our own observations and internal discussions, we revised the SES description as needed. Each addition or elimination was discussed and agreed amongst the authors of this paper. 
The success of the initiatives to achieve collective action served as an indirect indicator of the sustainability of the three systems. We used a simple three-step scale to assess this success:

1. Unsuccessful: no interest to engage in collective action was found in the community;

2. Partly successful: some interest was stated or demonstrated, but there was no follow-through;

3. Successful: interest was clearly demonstrated and followed by action, whether by building on existing initiatives or initiated by our research.

\section{Description of social-ecological systems}

Table 2 provides an overview of the basic ecological and socio-economic characteristics of the three case studies and of Slovenia as a whole.

\section{CS1: 'Solčavsko' - agri-forestry in sub-alpine Slovenia}

This case study investigated agriculture and forestry in the Upper Savinja Valley, in the municipalities Solčava and Luče. The entire area is hilly or mountainous. A total of $80 \%$ of the territory is forested and forestry is the main source of income for many farms (Mavsar 2005), supplemented by farming (mostly animal husbandry) and agri-tourism. Traditional farming practices (extensive grazing and harvesting) on large family farms and restrictive forestry policy (ZGS 2012) created a characteristic HNV landscape with

Table 2. Selected socio-economic and ecological indicators for each case study and Slovenia as a whole. Source: SURS (2018); MKGP-RKG (2018); http://www.natura2000.si/index.php?id=45.

\begin{tabular}{lcccc}
\hline & CS1 & CS2 & CS3 & Slovenia \\
\hline Size [km²] & 213 & 578 & 31 & 20,273 \\
Inhabitants (2018) & 1,985 & 25,899 & 1,977 & $2,066,880$ \\
Population ratio 2018/2008 & 0.97 & 0.95 & 0.92 & 1.02 \\
Average age (2018) & 43.93 & 45.18 & 45.70 & 43.20 \\
\% over 65 y.o. (2018) & 19.9 & 21.5 & 22.3 & 19.4 \\
Total farm area [ha] & 10,187 & 30,686 & 1,623 & 897,769 \\
$\quad$ Forest [\%] & 69.8 & 25.3 & 22.2 & 41.6 \\
$\quad$ UAA (2010) [\%] & $7.1^{\mathrm{a}}$ & 37.8 & 37.4 & 23.4 \\
$\quad$ Permanent grasslands and pasture [\%] & $96.4^{\mathrm{a}}$ & 20.7 & 16.4 & 58.5 \\
$\quad$ Field plots [\%] & $0.6^{\mathrm{a}}$ & 76.1 & 80.5 & 35.9 \\
$\mathrm{~N}^{\circ}$ Agricultural holdings (2010) & 211 & 3652 & 191 & 74455 \\
Average farm size (total farm area) [ha] (2010) & 48.1 & 8.4 & 8.5 & 12.0 \\
Utilized agricultural area /farm [ha] (2010) & $7.1^{\mathrm{a}}$ & 6 & 6.4 & 6.4 \\
ANC [\%] & 100 & $76^{\mathrm{a}}$ & $23^{\mathrm{a}}$ & 86.3 \\
N2K [\%] & 61.5 & 77.8 & 50 & 37.16 \\
\hline
\end{tabular}

aestimate; ANC: Area with natural constraints for farming 
Table 3. Summary of the main elements of studied SES. Source: authors.

\begin{tabular}{|c|c|c|c|}
\hline & Solčava & Goričko & Središče \\
\hline $\begin{array}{l}\text { Social, economic, } \\
\text { and political settings }\end{array}$ & $\begin{array}{l}\text { Post-transition situation, EU } \\
\text { accession, lagging incomes, } \\
\text { increasing demand for } \\
\text { products with higher value- } \\
\text { added }\end{array}$ & $\begin{array}{l}\text { Post-transition situation, EU } \\
\text { accession, lagging incomes, } \\
\text { increasing demand for } \\
\text { products with higher value- } \\
\text { added, agricultural } \\
\text { intensification, cultural } \\
\text { specificity }\end{array}$ & $\begin{array}{l}\text { Post-transition situation, EU } \\
\text { accession, lagging incomes, } \\
\text { increasing demand for } \\
\text { products with higher value- } \\
\text { added, agricultural } \\
\text { intensification }\end{array}$ \\
\hline Resource systems & $\begin{array}{l}\text { Alpine forests and agricultural } \\
\text { land (grassland) with high } \\
\text { biodiversity and cultural value }\end{array}$ & $\begin{array}{c}\text { Hilly agricultural mosaic } \\
\text { countryside and forests with } \\
\text { nearby hot springs; rich } \\
\text { cultural and culinary tradition }\end{array}$ & $\begin{array}{l}\text { Riparian forest and mosaic } \\
\text { agricultural landscape, } \\
\text { cultural tradition }\end{array}$ \\
\hline Governance systems & $\begin{array}{l}\text { Forest and agricultural policy; } \\
\text { engagement of municipality, } \\
\text { local NGOs, invested } \\
\text { individuals; park management } \\
\text { regime }\end{array}$ & $\begin{array}{c}\text { Agricultural and } \\
\text { environmental policy; } \\
\text { engagement of Landscape } \\
\text { Park management; park } \\
\text { management regime, N2K } \\
\text { rules }\end{array}$ & $\begin{array}{c}\text { Agricultural, environmental } \\
\text { and forest policy; engagement } \\
\text { of national NGO and } \\
\text { municipality; N2K rules }\end{array}$ \\
\hline $\begin{array}{l}\text { Resource units } \\
\text { (environmental and } \\
\text { social services) }\end{array}$ & $\begin{array}{l}\text { High biodiversity in semi- } \\
\text { (pasture) and pseudo-natural } \\
\text { (forest) habitats, including } \\
\text { animal genetic resources; } \\
\text { products (food, feed, wood, } \\
\text { wool); recreation and public } \\
\text { health, rural vitality }\end{array}$ & $\begin{array}{l}\text { High biodiversity in semi- } \\
\text { natural habitats, products } \\
\text { (food), recreation }\end{array}$ & $\begin{array}{l}\text { High biodiversity in natural } \\
\text { (riparian forest) and semi- } \\
\text { natural (mosaic agricultural } \\
\text { landscape) habitats, rural } \\
\text { vitality, products (food), } \\
\text { recreation }\end{array}$ \\
\hline Actors & $\begin{array}{l}\text { Strong local leader, engaged } \\
\text { municipality, invested } \\
\text { individuals, local NGOs } \\
\text { (associations), research group }\end{array}$ & $\begin{array}{l}\text { Park management, engaged } \\
\text { municipalities and national } \\
\text { extension service officers, } \\
\text { research group; low levels of } \\
\text { cooperation }\end{array}$ & $\begin{array}{l}\text { Strong local leader, engaged } \\
\text { municipality, invested } \\
\text { individuals, national NGO } \\
\text { and local NGOs } \\
\text { (associations), research group; } \\
\text { low levels of cooperation }\end{array}$ \\
\hline
\end{tabular}

well-preserved biodiversity (many rare or protected plant (e.g. Taxus baccata, Cypripedium calceolus, Primula auricula) and animal (e.g. Tetrao urogallus, Lynx lynx)) species and stable productive forest ecosystems, the wood of which is considered to have special technical properties due to high altitudes and traditional selective felling practices that take into account (supposed) seasonal and lunar influences (Lipnik et al. 2009).

In the 1970s and 1980s, this area became a mass tourism destination (Anko et al. 2007). Due to the accompanying pollution, some natural values were protected in 1987 , including two landscape parks - Logarska Valley (2430 ha) and Robanov kot (1447 ha) that represent a significant proportion of the case study area. A private company uniting landowners in Logarska Valley was granted management rights in 1992 and limited the number of tourists by introducing an entry fee and a relatively strict protection regime. The valley became a well-known destination for nature lovers, and residents of the park and its surroundings prospered through rural tourism and gastronomy.

Traditional HNV farming practices, mainly extensive grazing with cattle and sheep of predominantly autochthonous breeds adapted to the harsh environment (cika cattle and Jezersko-Solčava sheep), are today threatened by trends such as emigration from marginal areas and subsequent overgrowth; subsistence crop farming has already disap- 
Table 4. Main elements of action research. Source: authors.

\begin{tabular}{|c|c|c|c|}
\hline Action situation & Solčava & Goričko & Središče \\
\hline \multirow[t]{5}{*}{ Current state } & overgrowth & rapid overgrowth & agricultural intensification \\
\hline & farm abandonment & $\begin{array}{c}\text { proliferation of invasive alien } \\
\text { species }\end{array}$ & low incomes \\
\hline & depopulation & $\begin{array}{l}\text { abandonment of traditional } \\
\text { farming }\end{array}$ & depopulation \\
\hline & low value added & $\begin{array}{c}\text { depopulation and aging/ } \\
\text { intensification and } \\
\text { consolidation }\end{array}$ & \multirow[t]{2}{*}{$\begin{array}{l}\text { no cooperation of producers } \\
\text { and other service providers }\end{array}$} \\
\hline & low producer cooperation & $\begin{array}{c}\text { lack of cooperation, trust and } \\
\text { entrepreneurship }\end{array}$ & \\
\hline \multirow[t]{4}{*}{ Desired state } & $\begin{array}{l}\text { Preserved traditional grazing } \\
\text { and thus grassland habitats }\end{array}$ & $\begin{array}{l}\text { Improved cooperation amongst } \\
\text { farmers and with the park }\end{array}$ & $\begin{array}{l}\text { Preserved mosaic landscape } \\
\text { and natural habitats }\end{array}$ \\
\hline & $\begin{array}{c}\text { Preserved animal genetic } \\
\text { resources }\end{array}$ & $\begin{array}{c}\text { Developed coordinated supply } \\
\text { of value-added products }\end{array}$ & \multirow{3}{*}{$\begin{array}{c}\text { Economically and ecologically } \\
\text { sustainable exploitation of } \\
\text { natural assets through park } \\
\text { umbrella brand }\end{array}$} \\
\hline & Preserved forest ecosystems & Employment opportunities & \\
\hline & $\begin{array}{l}\text { Improved value-added and } \\
\text { consequently rural vitality }\end{array}$ & $\begin{array}{c}\text { Maintained population and } \\
\text { consequently land } \\
\text { management }\end{array}$ & \\
\hline Result & $\begin{array}{c}\text { Unsuccessful (agriculture) } \\
\text { Successful (forestry) }\end{array}$ & Partly successful & Successful \\
\hline
\end{tabular}

peared almost completely. Pastures, especially more remote ones, are preserved largely due to the public payments for the preservation of farming on Less Favoured Areas and related agri-environmental measures under the EU's Common Agricultural Policy. In addition, the traditional, locally adapted breeds are threatened, a decline in their populations only being prevented by agricultural policy measures, the engagement of individuals (also within breeding and related associations) and, more recently, by increasing consumer interest in 'local' and 'traditional' products. Part of the problem is the difficult transport and distance of processing facilities for local produce (milk, beef, lamb), as well as a highly seasonal character of direct sales channels (mainly through tourism and gastronomy), which result in lower and more volatile incomes.

The forest ecosystems are threatened by growing numbers of natural disasters due to climate change, for example widespread damage due to sleet in 2014 and strong winds in 2017, exacerbated by subsequent damage by pests and affecting the species structure. Continued sustainable management requires coordinated replanting efforts and an improved ability to compensate for increased management costs.

\section{CS2: 'Goričko' - Agriculture-based development strategies for areas hit by the economic crisis}

In CS2, a hilly agricultural landscape in the northeast of Slovenia was analysed; it included 11 municipalities, most of the territory of which falls under the Goricko Landscape Park established in 2003. It is the second largest protected area in Slovenia, protecting 38 animal species, one plant species and seven habitats identified and protected under the Natura 2000 framework (KPG 2018) and containing an aesthetically 
and environmentally valuable cultural landscape co-created by traditional subsistence mixed farming. The Park has agricultural holding status and directly manages 40.5 ha of land; its activities are aimed at maintaining the traditional sustainable land use system and the livelihood of small farmers.

The small subsistence mixed farms, which have historically contributed to the creation of the diverse mosaic of biodiversity-rich cultural landscapes, typically bred a small number of cattle and perhaps pigs, and tended to some arable land and grasslands, orchards and vineyards. Most of these farms are uncompetitive nowadays and the landscape is threatened by overgrowth due to the abandonment of traditional farming; conversely, parts where mechanised agriculture is possible are intensifying, giving way to a smaller number of specialised apple producers and dairy farmers, threatening the typical wet and dry grassland habitats. The rapid decline of these habitats (Government of the RS 2015) is exacerbated by the intrusion of invasive plants (especially Solidago sp.). As small-scale livestock farming has disappeared, farmers only perform late mowing of grass to receive subsidies. Two challenges are associated with late mowing. First, the acquired biomass is not suitable for animal feed and thus has limited economic potential. Second, late mowing accelerates the growth of invasive plants. Monitoring of bird (Upupa epops, Otus scops and Lullula arborea; Denac et al. 2017) and butterfly (Euphydryas aurinia, Phengaris nausithos and Phengaris teleius; Verovnik 2015; Zakšek et al. 2017) populations show a marked decline in abundance, indicating ineffectiveness of agricultural policy measures. Park conservation activities have been successful in improving butterfly abundance (Verovnik 2015), but long-term effects require systemic action.

The region's economy is underdeveloped in terms of average net earnings and offfarm job availability, and based on agriculture; in some municipalities, over half of the working population is employed in agriculture (SURS 2018). Following the collapse of large manufacturing plants during the transition, the area faces high unemployment, depopulation and aging; many seek employment elsewhere, leaving behind the older, less educated and less proactive. There is no active cooperative in this area and no market organisation; distrust and passivity (Klemenčič 2011) are traditionally strong.

Many individuals and institutions are working to mitigate these trends, including the Park administration, municipalities, agricultural advisory service etc., and the region is eligible for preferential financial assistance from EU and national sources. However, measures have generally failed to stem negative demographic and ecological trends. The Park administration is mistrusted by many farmers, seen as an obstacle to intensification and development. As a result, most refuse to participate in its activities, including joint marketing of products under a collective brand. The public recognises the region as an attractive tourist destination, but green tourism is in its infancy.

\section{CS3: 'Središče' - Nature conservation enabling social security in farming}

The third example covers an agricultural landscape (ca. 200 ha) and riparian forest (ca. $230 \mathrm{ha})$ in the municipality Središče ob Dravi in NE Slovenia. It contains the best pre- 
served lowland river ecosystem of riparian forest in Slovenia, with nationally important populations of a number of animal species (Charadrius dubius, Actitis hypoleucos, Alcedo atthis, Haliaeetus albicilla, Umbra krameri, Cobitis taenia, Cucujus cinnaberinus); the area, including some agricultural land, falls under the framework of biodiversity-rich Natura 2000 areas. Recently, there have been indications that the hamster Cricetus cricetus has re-appeared; it is the only part of Slovenia with habitats suitable for this species, so an area of approx. $2.5 \mathrm{~km}^{2}$ was proclaimed as a Natural Asset of national importance in 2004 .

The riparian forests in the immediate vicinity of the river are not commercially interesting for intensive logging; they are managed under forest management plans emphasising their nature conservation function. The agricultural landscape is a mosaic of meadows, small fields and hedgerows exposed to annual flooding. Historically, most farmland was grassland, but agricultural policy in the 1960s stimulated conversion to arable land, consolidation and intensification, even in erosion-prone waterfront areas. Despite this risk, these fields are cultivated by farmers receiving CAP direct payments, often participating in the national scheme providing for subsidised crop insurance. Some waterways face eutrophication.

The area is remote and economically very weak. Many farmers are older and not developing any supplementary activities, but try to compete by reducing costs and intensifying production, yet even the largest farms in the region are relatively small and are in an unfavourable economic position. On the other hand, some younger farmers have invested in processing and some offer tourist and leisure services or gastronomic products. Several associations (beekeeping, tourist, equestrian, hunting) are also active but insufficiently coordinated for the development of a comprehensive range of tourist products and services, which is also limited by a lack of accommodation.

Cooperation between farmers and members of value chains is also weak; there is little organised production or coordinated marketing activity. Many farmers traditionally produce pumpkin seeds and sell them to a local oil mill that produces pumpkin oil, a gastronomic speciality, and attracts thousands of visitors annually.

Due to the rich natural (and cultural) heritage, several attempts have been made to establish a Landscape Park. The first, in the 1990s, failed due to unrelated disputes and the non-inclusive nature of the decision-making process, which deterred the locals; the second was at the time of our study. The mayor, in cooperation with a national conservation $\mathrm{NGO}$, renewed the initiative to establish a park, insisting that a condition for its establishment is support by the inhabitants.

\section{Results of action-based research}

\section{CS1: Solčavsko}

During the focus groups, two sustainability issues emerged as crucial: the decline of traditional extensive pastoralism and a general decline of rural vitality due to low incomes, which are both a consequence of the unattractive economic position of farming and low availability of jobs outside agriculture. The solution can be to develop value- 
added products. Therefore, our action research investigated the capacity and readiness of land managers to cooperate in two integrated value chains that emerged as crucial during focus group discussions:

1) marketing of local sheep breed products (meat, processed products, wool); specifically, we investigated the possibility of establishing a small local processing facility and collective marketing efforts;

2) cooperation in a project improving the marketing of Mountain Wood by participating in a consortium of producers, processors, designers, certifiers and scientists; its purpose would be to scientifically assess the supposedly special properties of this material, develop products and improve consumer awareness in order to establish an autonomously functioning value chain.

Regarding the first initiative, interviews and a follow-up focus group revealed that breeders have no real interest in increasing production but prefer to sell products individually, either as part of their on-farm tourist offer or in informal markets. They would only market surpluses and are not interested in joining forces to ensure a consistent supply of meat. Some opinion leaders even expressed opposition to the idea. While one of the farmers is planning to invest in a small-scale processing facility, we did not detect any interest in collective action, so this part of the action research was deemed unsuccessful.

The project of improving the valorisation of Mountain Wood was initiated by a former mayor, who is himself a forest owner and employee of the State Forest service and has been working on the market valorisation of Mountain Wood for several years. Based on past experience and collaboration, we invited producers, processors and experts to cooperate in the project; the response was favourable and an intention to cooperate was publicly proclaimed, endorsed by the Ministry of Agriculture, Forestry and Food. The consortium is working on a project application to acquire funding to establish the value chain. We thus judged this part of the research as successful, though the long-term success of the initiative remains to be demonstrated.

\section{CS2: Goričko}

Within the focus groups with representatives of the municipalities, park and advisory services, the distrust and conservatism of (especially elderly) farmers emerged as a major obstacle to cooperate in initiatives that could improve the valorisation of the preserved landscape. As community relations between farmers were the greatest issue, before pursuing immediate common economic goals, a 'collective' had to be established in the first place. Therefore, our action research mostly took place in workshops and put a stronger emphasis on (younger) farmers and examined their willingness to cooperate, with the idea that an association of young farmers could serve as a nucleus around which economic cooperation and developmental projects could develop. At first, there seemed to be a critical mass present: they demonstrated some readiness and 
set up an initiative group to form a Rural Youth Association. However, the initial enthusiasm declined within one year; subsequent interviews indicated that the key issue was the lack of a leader, common economic interest (different production orientations, disagreement between conventional and organic farmers) and common identity (different social backgrounds). We therefore assessed the case as partly successful.

\section{CS3: Središče ob Dravi}

In the third case, our research coincided with an on-going discussion at the municipal level on the establishment of a Landscape Park initiated by the national NGO and endorsed by the mayor, who sees the park as a development opportunity. Therefore, based on the conclusions of the focus group, we investigated the attitudes of farmers and other residents towards its establishment, as well as their willingness to participate in a comprehensive tourist offer within the park as an umbrella brand. Most interviewees were very sympathetic to the Park and only a few large farmers feared the management regime (despite the fact that it would not bring new restrictions on agriculture); they cited negative past experience with the introduction of Natura 2000. While the Municipal Council initially voted against the establishment of the Park (12/2017), it was established on 4/2019 (after the conclusion of the study), so the case can be considered successful.

\section{Analysis - Comparison of the Case studies}

Our findings indicate that the most important components of the observed SES influencing sustainable trajectories fall into the categories Actors, Macro issues - Social, Economic and Political Setting, and Governance Systems; the systems of natural resources themselves seemed to be less influential, while the private and public goods (resource units) derived from them appear more as a dependent variable. Below, we discuss the major sets of influential variables.

\section{Actors}

The characteristics of actors proved to be essential for the results (see also, for example, Olsson et al. 2004; Folke et al. 2005) and can be roughly divided into two groups:

\section{Perception of the situation, personal interest and values}

The perception of the system state as critical by opinion leaders greatly influenced whether or not the will and critical mass to cooperate were present in the system. 
Thus, in CS1, there was a lack of interest in the collective effort in the marketing of agricultural (i.e. extensive livestock) production as they did not see sufficient benefits for themselves in cooperating. The same is true of farmers' willingness to cooperate in grassland conservation in CS2, where an additional role was played by the dominant view amongst farmers of the interests of agriculture and nature protection as irreconcilable. In addition, the perception of the situation (habitat decline) as critical from the Park management's point of view was not shared by farmers, nor was the Park director perceived by them as an opinion leader.

In CS3, as well, the perception of the Park by large farmers (opinion leaders) as a threat to agriculture was decisive for the initial failure. Over time, the mayor's personal effort, sharing of positive experiences from elsewhere, the activities of our research team and pressure from the wider local community did however manage to gain critical mass to establish the Park.

Moreover, in the case of mountain timber valorisation, the professional and personal engagement of the former mayor was undoubtedly an essential element; nor are the motivations (professional and/or economic) of other members of the consortium (local entrepreneurs, representatives of professional institutions) a negligible factor.

\section{Community relations and socio-economic traits of actors}

In CS1, there was a marked contrast between the two initiatives. The failure of the agricultural initiative was partly attributable to the negative previous experience with the failed establishment of a local slaughterhouse and processing facility, which left in its wake cynicism and eroded trust and willingness to cooperate. Conversely, the Wood initiative built upon earlier successes in promoting the material (including the historical importance of forestry as a source of income and even wealth) and even more on the engagement of the former mayor, a respected and trusted member of the community.

The mayor in CS3, too, invested considerable energy in establishing trust and communication with stakeholders and avoiding repetition of past mistakes. This effort was required to overcome the opposing distrust of farmers towards conservation efforts related to the negative experience with Natura 2000.

In CS2, the distrust of farmers towards the Park and its management, which they see as hampering economic development, seems to be insurmountable at the moment. This may be related to the traditional passivity and mistrust present in the region, as well as the lack of an accepted local leader.

Both in CS3 and in CS2, the low levels of education and low socioeconomic status are related to risk-aversion and resistance to change; this is in contrast with CS1, where the large farm-holders have traditionally been more entrepreneurial and prepared (and able) to invest long-term, but at the same time more individualistic.

The post-transitional context did play a relevant role in all cases. On the one hand, there is a pervasive idea that when something is amiss, 'the state ought to...', indicating a dependence or at least accustomedness to the social state (cf. Scrieciu 2011). On 
the other hand and perhaps more importantly, the memory of forced collectivisation of property after World War II (though agricultural land itself was not subject to largescale collectivisation in Slovenia, see Lerman 2001) and the associated phenomenon of free-riding is still raw and seems to continue to be a powerful deterrent to collective action. Crucially for market-based valorisation of public goods stemming from HNV farming, the readiness to cooperate economically and engage in a mutually-dependent activity where trust is a prerequisite, is only in its infancy.

Finally, the role of the research group in cooperation with the gatekeepers should be noted. In CS3, the Mountain Wood initiative, the engagement of agricultural policy and wood science specialists was an important element, and the good reputation that some of the group's members enjoy in the agricultural community contributed towards the readiness of farmers to communicate, especially in CS3.

\section{Macro issues - Social, economic and political settings}

Societal change is, in all three cases, the element threatening the system in the first place. Subsistence farming is coming under pressure from economic and political changes that are forcing intensification or farm abandonment (cf. McGinlay et al. 2017). The seminatural habitats which resulted from traditional sustainable practices are collateral damage of this pressure. It was stated in all three cases by farmers that they would rather receive a 'fair' market price than be dependent on subsidies. Many inhabitants of traditional farming landscapes are financially poor and from their perspective, development is desirable, which threatens biodiversity and cultural heritage (Fischer et al. 2012).

On the other hand, consumer preferences are changing and demand for differentiated, high value-added products is increasing. This represents an opportunity for farmers who are able to adapt by diversifying, but also demands the (collective) development of appropriate market channels, as these areas are remote, isolated from urban markets and demand (cf. Scrieciu 2011).

Demographic trends appear both as an exogenous and endogenous variable. On the one hand, there are general societal trends of population aging and on the other hand, many young people are leaving the sector (and thus the countryside in general) because of lower incomes and poorer general services in rural areas (MAFF 2019), as well as because of the relatively negative societal perception (Černič Istenič 2011) of agriculture in Slovenian society. At the same time, there is a de-urbanisation trend emerging, especially in CS2, where some newcomers are also involved in agriculture. However, due to different value systems, they are mostly less integrated into the local community here.

\section{Governance systems}

Agricultural policy, especially the Common EU Agricultural Policy (CAP), has the strongest influence in this category, with significant impact on farmers' production de- 
cisions. It is particularly problematic due to inconsistencies in terms of nature conservation signals (Pe'er et al. 2017). On the one hand, farmers receive different payments from the agri-environmental scheme system and, on the other hand, direct payments allow for intensification of production and to some extent stimulate it. While income support contributes to the preservation of farming and supports young entrants, and cross-compliance arguably demands adherence to some basic environmental standards, these payments also cushion famers from market signals (Bureau et al. 2012), inhibiting development and adaptation.

The inadequate substantive design of the measures also has weak effects on the conservation of biodiversity (see, for example, European Court of Auditors 2011, 2017). Examples include poor design of agricultural policy measures for the conservation of butterflies contrasted with more effective locally-adapted measures adopted by the Park in CS2 (Verovnik 2015). The measure for conserving traditional breeds, relevant in CS1, is also inadequate given the declining population; according to interviewees, it is just not attractive to farmers. On the other hand, the Mountain Wood initiative is applying for funding under the CAP's rural development policy (a measure supporting the cooperation between farmers, advisors and researchers).

In terms of influencing outcomes, the aforementioned negative experience of farmers with Natura 2000, perceived as a restriction to farming, is an important factor. On the other hand, it is a condition for eligibility for funding under certain schemes. Nevertheless, it is mostly perceived as an obstacle rather than as an opportunity, especially in CS3 and CS2.

Despite not being formal rules, the rules-in-use regarding the transparency and inclusivity of the decision-making process must be mentioned. Most notably, striving for legitimacy yielded positive results in CS3 and CS1 (wood), while the perception of the Park as imposed in CS2 contributed to farmers' negative attitudes.

In all the observed SESs, the problem of combined property regimes is present (cf. Seixas and Berkes 2003), accompanied by colliding public and private interests. Agricultural intensification (the pursuit of a perfectly legitimate private interest, i.e. higher incomes) directly influences environmental (biodiversity) and social (cultural landscape) public goods. This contrast was most strongly present in CS3, where strong private interests initially prevailed over common ones, as well as over weaker/dispersed private ones.

\section{Resource system}

The size of the resource system in itself did not seem to be a crucial variable affecting results. CS1 is a good example of this, as the size of the system in the two initiatives was essentially the same; rather, the success seemed more dependent on other elements listed above, such as community relations and actor traits. Similarly, the intensity of management in itself did not appear to be a critical factor, with the possible exception of CS3, where large farmers were the ones most strongly opposing collective action; however, this again seems more strongly related to their economic dependence than to management intensity as such. 


\section{Discussion}

Generally, it can be said, based on our research, that there is some awareness amongst farmers from HNV farming systems of the importance of valorising products through markets by turning the fact that they provide a socially-desirable service into a marketable trait - an attribute of value-added. On the other hand, the notion of cooperating to achieve market access more easily is not entertained nearly as much as the one that the state 'ought' to make this value better recognised somehow (preferably through measures like price control or import charges, supposedly a thing of the past in the EU). While they view that the larger collective must recognise the service that they make to it, they do not - ironically - take the individual responsibility that is required for the success of collective action; in many cases, this may simply be attributed to the farmers' relatively high age and low levels of education, but it is also a still-pervasive communist mindset, legacy of the communist period (1945-1990, see also Scrieciu 2011).

Some of the mistrust towards collective action, encountered in our case studies, may also be attributable to the anomalies and controversy occurring during the process of privatisation of socially-owned property (Lorenčič 2016) and which still plagues the Slovenian media space today. By contrast, the relative success of our research group as representatives of a respectable institution in functioning as a cohesive element (granting credibility to the initiatives; cf. Lawrence 2008) suggest the possibility that, in communities where trust is low, external institutional support may be an appropriate interim way of stimulating collective action. This includes policy measures, of which the Rural Development Policy (RDP) measure applied to by the Wood initiative is an apt example.

Our research confirmed the importance of leaders that was found in previous similar studies on community resource management conducted in Western contexts (e.g. Olsson et al. 2004; Folke et al. 2005); interestingly, this issue does not seem to have received as much attention in literature focussing on community-based resource management in the CEEC, with the exception of Mike and Megyesi (2018), who highlight the presence of a leader as an important determinant of success in Common Pool Resource (CPR) management. However, the presence or absence of leaders is a factor that is particularly difficult to influence.

HNV farming ecosystems are complex SESs in which the private and the public intersect. While they can be considered as private resource management systems, there is also a distinctive element of commonality in them, as they collectively provide a number of public goods to society, necessitating collective action to ensure their future sustainable provision. Thus, the problem with which we are faced in managing them is somewhat different from the classical conceptualisation of SESs as (collectively) managed systems of resource abstraction. Dwyer et al.'s (2018) modification of the framework that conceptualises agri-food systems as joint providers of environmental and social services (benefits) has proven its utility in our analysis of such systems.

While HNV farming systems that are declining due to intensification are somewhat more straightforward in that ensuring their sustainability 'only' demands limit- 
ing the overuse of resources, systems declining due to abandonment are not 'solved' as easily. Here, the interplay of the social and ecological elements of the systems comes readily to the forefront, as the desired outcomes would not be produced by either subsystem alone. This aspect also confirms the appropriateness of adopting an SES-based approach to analysis.

Admittedly, the definition of a sustainable SES and desirable outcomes is valueladen. It is precisely values that offer themselves as an obvious factor determining system trajectories. In addition to determining our definition of what constitutes a sustainable system (i.e. one that preserves wild and man-made biodiversity, cultural landscapes and sustains rural communities), the internalisation of common values is a precondition for collective action (Wright 2009). Perhaps the transition from communism to capitalism as a transition between value systems (Musek 1997) helps to explain why collective action seems difficult to achieve. We conjecture that, given the facts that Slovenia is amongst the westernmost of the post-communist countries that remained closest to the West-European value circle (ibid.) and was a constituent of (ex-)Yugoslavia with its market socialism (Estrin 1991), its transition should also be easiest; this may mean that other post-communist countries may experience difficulty in achieving sustainable resource management through market-based collective action for even longer. Historical context will, in our view, likely play an important role in the specific developments in each country (cf. Tickle and Clarke 2000; Scrieciu 2011).

Moreover, there is a more current transition between clashing value systems that is particularly visible in agriculture, namely that of farmers adhering to the productivist credo and environmentalists (cf. Burton and Wilson 2006). This is not simply a clash of ideologies; to many farmers, these changing societal values represent a threat to their livelihoods; the natural response of numerous, especially older farmers, is indignation.

Turning to the limitations of our study, the fact that many of the variables described are unmeasurable represented a serious research obstacle. While it is true that the primary intent of our study was not to exactly measure all SES elements, but to understand the system and its interactions, the lack of quantifiable variables makes comparison between the physical elements of different systems difficult. The second drawback of our research is its relatively short time span and definition of the 'success' of the action situation (i.e. stimulating collective action); truly observing the system and its dynamics would undoubtedly require longitudinal research.

\section{Conclusions}

Preserving HNV farming plays an important role in conserving biodiversity. This paper attempts to address the gap related to sustainable resource management that exists in the commons literature in the CEEC by exploring ways to motivate land managers to engage in collective action that would enable them to receive remuneration for their provision of public goods through the market.

We used the Social-ecological systems framework to describe the observed systems and approached our comparative analysis in two steps; in the first, we described the 
systems' main variables, while in the second, we attempted to actively influence their trajectories. This was done in cooperation with local actors. We found that the characteristics of system actors had the greatest influence on outcomes, while wider social, economic and political influences are those that are pushing the systems out of balance in the first place, but are also providing new opportunities.

While we have attempted to provide a cross-case synthesis, it is clear that it is very difficult to construct a single success formula, as every system is different; however, we can conclude that it seems necessary that a strong leader (or leaders) is present who enjoys the community's trust; rules must be transparent and individuals must have a personal interest to engage in cooperation. Considering the post-transitional settings, overcoming the issue of lack of trust was certainly the limiting factor in all cases when attempting to stimulate collective action. Despite increasing amounts of policy support, this rather unfavourable setting is unlikely to be conducive to large-scale shifts towards environmentally-conscious collective market action; rather, what we are more likely to witness in the foreseeable future are individual success stories.

\section{Acknowledgements}

The research described in this paper was partly conducted under the EU Horizon 2020 project PEGASUS - Public Ecosystem Goods and Services from land management Unlocking the Synergies, under grant agreement No 633814.

\section{References}

Anko B, Anteric M, Clarke R, Koščak M, Lenar A, Mitchell I, Slapnik M (2007) Študija o Solčavskem 1932-2007: Poročilo o skupnem terenskem delu Univerze v Ljubljani in Univerze v Londonu 1932-2007 [Study on Solčavsko 1932-2007: Report on fieldwork conducted by the University of Ljubljana and University of London 1932-2007]: 1-119.

ARSO (2008) Kmetijska območja visoke naravne vrednosti [High natural value farming areas]. Agencija Republike Slovenije za okolje [Slovenian Environment Agency]. http://kazalci. arso.gov.si/sl/content/kmetijska-obmocja-visoke-naravne-vrednosti

Bureau J-C, Tangermann S, Matthews A, Viaggi D, Crombez C, Knops L, Swinnen J, Bureau J-C (2012) The Common Agricultural Policy after 2013. Intereconomics 47(6): 316-342. https://doi.org/10.1007/s10272-012-0435-6

Burton RJ, Wilson GA (2006) Injecting social psychology theory into conceptualisations of agricultural agency: Towards a post-productivist farmer self-identity? Journal of Rural Studies 22(1): 95-115. https://doi.org/10.1016/j.jrurstud.2005.07.004

Černič Istenič M (2011) Medijska podoba kmetijstva in kmeta v Sloveniji. [The media image of agriculture and farmers in Slovenia] In Politike reprezentacije v Jugovzhodni Evropi na prelomu stoletij, Kulturni spomin: 76-99. 
Cooper T, Hart K, Baldock D (2009) Provision of public goods through agriculture in the European Union. Institute for European Environmental Policy, London, 1-396.

Cornwall A, Jewkes R (1995) What is participatory research? Social Science \& Medicine 41(12): 1667-1676. https://doi.org/10.1016/0277-9536(95)00127-S

Costanza R, d'Arge R, De Groot R, Farber S, Grasso M, Hannon B, Limburg K, Naeem S, O'Neill RV, Paruelo J, Raskin RG, Sutton P, van den Belt M (1997) The value of the world's ecosystem services and natural capital. Nature 387(6630): 253-260. https://doi. org/10.1038/387253a0

Cumming GS (2014) Theoretical frameworks for the analysis of social-ecological systems. In: Social-Ecological Systems in Transition. Springer, Tokyo, 3-24. https://doi. org/10.1007/978-4-431-54910-9_1

Daily GC (1997) Nature's services. Island Press, Washington, DC.

Davidova S, Bailey A, Dwyer J, Erjavec E, Gorton M, Thomson K (2013) Semi-subsistence farming-value and directions of development, study prepared for the European Parliament Committee on Agriculture and Rural Development. Brussels: Directorate-General for Internal Policies, Policy Department Structural and Cohesion Policies.

Denac K, Kmecl P, Domanjko G, Denac D (2017) Population trends of Goričko agricultural landscape birds. Acrocephalus 38(174-175): 127-159. https://doi.org/10.1515/acro2017-0009

Díaz S, Settele J, Brondízio E, Ngo H, Guèze M, Agard J, Arneth A, Balvanera P, Brauman K, Butchart S, Chan K, Garibaldi L, Ichii K, Liu J, Subrmanian S, Midgley G, Miloslavich P, Molnár Z, Obura D, Pfaff A, Polasky S, Purvis A, Razzaque J, Reyers B, Chowdhury R, Shin Y, Visseren-Hamakers I, Wilis K, Zayas C (2016) Summary for policymakers of the global assessment report on biodiversity and ecosystem services of the Intergovernmental Science-Policy Platform on Biodiversity and Ecosystem Services, 1-39. https://www.ipbes. net/sites/default/files/downloads/spm_unedited_advance_for_posting_htn.pdf

Dwyer J, Berriet-Solliec M, Lataste FG, Short C, Maréchal A, Hart K (2018) A Social-Ecological Systems Approach to Enhance Sustainable Farming and Forestry in the EU. EuroChoices (Uckfield) 17(3): 4-10. https://doi.org/10.1111/1746-692X.12188

ESPON (2017) Policy brief. Shrinking rural regions in Europe. European Regional Development Fund, 1-15. https:/www.espon.eu/rural-shrinking

Estrin S (1991) Yugoslavia: The case of self-managing market socialism. The Journal of Economic Perspectives 5(4): 187-194. https://doi.org/10.1257/jep.5.4.187

European Commission (2019) Biodiversity and farmed landscapes. CAP specific objectives... explained. European Union, 1-19. https://ec.europa.eu/info/food-farming-fisheries/keypolicies/common-agricultural-policy/future-cap/key-policy-objectives-future-cap_en

European Court of Auditors (2011) Is Agri-environment support well designed and managed? Publications Office of the European Union, 1-82.

European Court of Auditors (2017) Greening: A more complex income support scheme, not yet environmentally effective. European Union, 1-63.

European Union (2018) Farming for Natura 2000. Publications Office of the European Union, Luxembourg, 1-146. 
Fischer J, Hartel T, Kuemmerle T (2012) Conservation policy in traditional farming landscapes. Conservation Letters 5(3): 167-175. https://doi.org/10.1111/j.1755-263X.2012.00227.x Folke C, Hahn T, Olsson P, Norberg J (2005) Adaptive governance of social-ecological systems. Annual Review of Environment and Resources 30(1): 441-473. https://doi.org/10.1146/ annurev.energy.30.050504.144511

Government of the RS (2015) Slovenian Natura 2000 management programme 2015-2020. Gruère G, Nagarajan L, King EO (2009) The role of collective action in the marketing of underutilized plant species: Lessons from a case study on minor millets in South India. Food Policy 34(1): 39-45. https://doi.org/10.1016/j.foodpol.2008.10.006

Hoogeveen Y, Petersen J, Balazs K, Higuero I (2004) High nature value farmland-characteristics, trends and policy challenges. Office for Official Publications of the European Communities, Luxembourg, 1-31.

Jarvis DI, Hodgkin T, Sthapit BR, Fadda C, Lopez-Noriega I (2011) An heuristic framework for identifying multiple ways of supporting the conservation and use of traditional crop varieties within the agricultural production system. Critical Reviews in Plant Sciences 30(1-2): 125-176. https://doi.org/10.1080/07352689.2011.554358

Keenleyside C, Beaufoy G, Tucker G, Jones G (2014) High Nature Value farming throughout EU-27 and its financial support under the CAP. Institute for European Environmental Policy, London, 10, 91086.

Klemenčič M (2011) Pomurje in regionalna identiteta Prekmurja. [Pomurje and regional identity of Prekmurje] http://www.drustvo-geografov-pomurja.si/projekti/zborovanje/zbornik/ aMarijan\%20M\%20Klemencic_T.pdf

KPG (2018) Program dela in finančni načrt za leto 2018 [Work and financial plan for 2018] Public institute Krajinski park Goričko, Grad, 1-85.

Kruijssen F, Keizer M, Giuliani A (2009) Collective action for small-scale producers of agricultural biodiversity products. Food Policy 34(1): 46-52. https://doi.org/10.1016/j.foodpol.2008.10.008

Lawrence A (2008) Experiences with participatory conservation in post-socialist Europe. The International Journal of Biodiversity Science and Management 4(4): 179-186. https://doi. org/10.3843/Biodiv.4.4:1

Lerman Z (2001) Agriculture in transition economies: From common heritage to divergence. Agricultural Economics 26(2): 95-114. https://doi.org/10.1111/j.1574-0862.2001.tb00057.x

Lipnik A, Medved M, Torelli N, Robek R, Poličnik T, Slapnik M (2009) Solčavski gorski les: študija o značilnostih in prednostih solčavskega gorskega lesa ter njegovi uporabnosti [Solčava Mountain wood: Study of the characteristics and advantages of Solčava Mountain wood and its utility]. Društvo lastnikov gozdov Tisa, Solčava - Ljubljana, 1-87.

Lomba A, Guerra C, Alonso J, Honrado JP, Jongman R, McCracken D (2014) Mapping and monitoring High Nature Value farmlands: Challenges in European landscapes. Journal of Environmental Management 143: 140-150. https://doi.org/10.1016/j.jenvman.2014.04.029

Lorenčič A (2016) Studying the Economic Transition-Challenges, Problems and Results. Prispevki za novejšo zgodovino (before 1960: Prispevki za zgodovino delavskega gibanja) 56: 59-70. 
MAFF (2019) Rural development programme of the Republic of Slovenia for the period 20142020.

Mavsar R (2005) Socio-ekonomski pomen gozdov v alpskem prostoru. [Socio-economic significance of forests in the Alpine region]. Zbornik gozdarstva in lesarstva 77: 143-158.

Maxwell JA (2012) Qualitative research design: An interactive approach (3rd ed., Vol. 41). Sage Publications.

McGinlay J, Gowing DJ, Budds J (2017) The threat of abandonment in socio-ecological landscapes: Farmers' motivations and perspectives on high nature value grassland conservation. Environmental Science \& Policy 69: 39-49. 7 https://doi.org/10.1016/j.envsci.2016.12.007

McGinnis MD, Ostrom E (2014) Social-ecological system framework: Initial changes and continuing challenges. Ecology and Society 19(2): 30. https://doi.org/10.5751/ES-06387190230

McIntyre A (2007) Participatory action research. Sage Publications. https:/doi. org/10.4135/9781483385679

Mike K, Megyesi B (2018) Communities after markets. The long road of winemakers to self-governance in post-communist Hungary. Geoforum 88: 129-137. https://doi.org/10.1016/j. geoforum.2017.11.021

MKGP-RKG (2018) Javni pregledovalnik grafičnih podatkov MKGP [Public database of graphical data of the MAFF]. http://rkg.gov.si/GERK/WebViewer/

Murray C (2005) Social capital and cooperation in Central and Eastern Europe: A theoretical perspective. https://www.ssoar.info/ssoar/handle/document/11738

Musek J (1997) The impact of transitional changes on value systems in Post-communist Europe: The implications for the higher education reform processes. Perspectives in Higher Education Reform 6: 15-22.

Musgrave RA (1959) Theory of public finance: a study in public economy. Mc Graw-Hill, New York, 628.

O'Rourke E, Kramm N (2012) High nature value (HNV) farming and the management of upland diversity. A review. European Countryside 4(2): 116-133. https://doi.org/10.2478/ v10091-012-0018-3

Olsson P, Folke C, Berkes F (2004) Adaptive comanagement for building resilience in socialecological systems. Environmental Management 34(1): 75-90. https://doi.org/10.1007/ s00267-003-0101-7

Ostrom E (2007) A diagnostic approach for going beyond panaceas. Proceedings of the National Academy of Sciences of the United States of America 104(39): 15181-15187. https://doi.org/10.1073/pnas.0702288104

Ostrom E (2009) A general framework for analyzing sustainability of social-ecological systems. Science 325(5939): 419-422. https://doi.org/10.1126/science.1172133

Otto I, Chobotova V (2013) Opportunities and constraints of adopting market governance in protected areas in Central and Eastern Europe. The International Journal of the Commons 7(1): 34-57. https://doi.org/10.18352/ijc.366

Partelow S (2018) A review of the social-ecological systems framework. Ecology and Society 23(4): 36. https://doi.org/10.5751/ES-10594-230436 
Pe'er G, Lakner S, Müller R, et al. (2017) Is the CAP fit for purpose? An evidence-based fitness check assessment. Stichting BirdLife Europe and the European Environmental Bureau, Leipzig.

Perpiña Castillo C, Kavalov B, Diogo V, Jacobs-Crisioni C, Batista e Silva F, Baranzelli C, Lavalle C (2018) Trends in the EU agricultural land within 2015-2030. Joint Research Centre, Seville, 1-6.

Samuelson PA (1954) The pure theory of public expenditure. The Review of Economics and Statistics 36(4): 387-389. https://doi.org/10.2307/1925895

Sandberg A, Theesfeld I, Schlüter A, Penov I, Dirimanova V (2013) Commons in a changing Europe. The International Journal of the Commons 7(1): 1-6. https://doi.org/10.18352/ ijc. 404

Sapsford R, Abbott P (2006) Trust, confidence and social environment in post-communist societies. Communist and Post-Communist Studies 39(1): 59-71. https://doi.org/10.1016/j. postcomstud.2005.12.003

Schoon M, Van der Leeuw S (2015) The shift toward social-ecological systems perspectives: Insights into the human-nature relationship. Nature Sciences Sociétés 23(2): 166-174. https://doi.org/10.1051/nss/2015034

Scrieciu SS (2011) Socioeconomic and environmental impacts on agriculture in the new Europe: Post-communist transition and accession to the European Union. Routledge. https:// doi.org/10.4324/9780203828502

Seixas CS, Berkes F (2003) Dynamics of social-ecological changes in a lagoon fishery in southern Brazil. In: Berkes F, Colding J, Folke C (Eds) Navigating social-ecological systems: Building resilience for complexity and change. Cambridge University Press, New York, 271-290. https://doi.org/10.1017/CBO9780511541957.017

SURS (2018) Baza SI-STAT. http://pxweb.stat.si/pxweb/dialog/statfile2.asp

Sutcliffe LM, Batáry P, Kormann U, Báldi A, Dicks LV, Herzon I, Kleijn D, Tryjanowski P, Apostolova I, Arlettaz R, Aunins A, Aviron S, Baležentienė L, Fischer C, Halada L, Hartel T, Help A, Hristov I, Jelaska SD, Kaligarič M, Kamp J, Klimek S, Kooberg P, Kostiuková J, Kovács-Hostyánszki A, Kuemmerle T, Leuschner C, Lindborg R, Loos J, Maccherini S, Marja R, Máthé O, Paulini I, Proença V, Rey-Benayas J, Sans FX, Seifert C, Stalenga J, Timaeus J, Török P, van Swaay C, Viik E, Tscharntke T (2015) Harnessing the biodiversity value of Central and Eastern European farmland. Diversity \& Distributions 21(6): 722-730. https://doi.org/10.1111/ddi.12288

Swain N (2000) The rural transition in post-socialist Central Europe and the Balkans. Max Planck Institute for social anthropology, Halle/Saale.

Tickle A, Clarke R (2000) Nature and landscape conservation in transition in central and southeastern Europe. European Environment 10(5): 211-219. https://doi.org/10.1002/10990976(200009/10) 10:5<211::AID-EET235>3.0.CO;2-8

Ustaoglu E, Collier MJ (2018) Farmland abandonment in Europe: An overview of drivers, consequences, and assessment of the sustainability implications. Environmental Reviews 26(4): 396-416. https://doi.org/10.1139/er-2018-0001

Uvalić M (2018) Special report: the rise and fall of market socialism in Yugoslavia. Dialogue of Civilizations Research Institute 27: 1-77. https://doc-research.org/2018/03/rise-fallmarket-socialism-yugoslavia/ 
Verovnik R (2015) Ekološke raziskave nekaterih vrst metuljev in učinkov KOP-MET ukrepov na Goričkem v letu 2015 [Ecological research on certain species of butterflies and the effects of KOP-MET measures in Goričko in 2015], 1-23. https://issuu.com/mojcapodletnik/docs/goricko-metulji-porocilo-2015

World Bank (2007) World Development Report 2008 (Overview): Agriculture and Development. World Bank, Washington, DC, 1-390. https://doi.org/10.1596/9780821368077_ Overview

Wright SC (2009) The next generation of collective action research. The Journal of Social Issues 65(4): 859-879. https://doi.org/10.1111/j.1540-4560.2009.01628.x

Zakšek B, Verovnik R, Zakšek V, Kogovšek N, Govedič M, Šalamun A, Grobelnik V, Lešnik A (2017) Monitoring izbranih ciljnih vrst metuljev v letu 2017 [Monitoring of selected butterfly species in 2017]. Center za kartografijo favne in flore, Miklavž na Dravskem polju, $1-103$.

ZGS (2012) Gozdnogospodarski načrt gozdnogospodarskega območja Nazarje (2011-2020) št.10/11 [Forest management plan of Nazarje area 2011-2020, n.10/11]. Slovenia Forest Service, Ljubljana, 1-321. 